\title{
Effect of temperature on growth rate of Aurelia aurita (Cnidaria, Scyphozoa) from Gullmarsfjorden, Sweden
}

\author{
Lars Johan Hansson* \\ Department of Marine Ecology, Göteborg University, Kristineberg Marine Research Station, S-450 34 Fiskebäckskil, Sweden
}

\begin{abstract}
Short-term laboratory experiments were carried out to investigate the effect of water temperature on somatic growth rate of the jellyfish Aurelia aurita (L.). Medusae of A aurita $(2.24$ to $32.0 \mathrm{~g}$ wet weight) with an initial excess food supply were kept at 1 of 4 temperatures (5.1, 10.0,16.4 and $19.0^{\circ} \mathrm{C}$ ). Daily weight-specific growth rate $(G)$ for each individual medusa was calculated from growth of the subumbrellar area, which was estimated from image analysis of video recorded medusae. Average value of $G$ increased significantly with temperature, and ranged from $0.053 \mathrm{di}^{\prime}$ at $5^{\circ} \mathrm{C}$ to $0.15 \mathrm{~d}^{-1}$ at $16.5^{\circ} \mathrm{C}$. The laboratory results were compared to in situ growth rates calculated from field observations of change in size of medusae from Gullmarsfjorden, western Sweden, 1993 to 1996. Specific growth rates in situ ranged from 0.11 to $0.16 \mathrm{~d}^{-1}$ Growth rates calculated from simulations of growth, based on laboratory-determined temperature-specific growth rates and surface water temperature in Gulmarsfjorden, were similar to or lower than in situ specific growth rates. In situ grow th of $A$. aurita cedsed in summer. This is suggested to be due to more energy being allocated to reproduction than somatic growth, food shortage, or a genetically determined cessation of somatic growth after reproduction.
\end{abstract}

KEY WORDS: Jellyfish - Medusa Image analysis Skagerrak

\section{INTRODUCTION}

Water temperature has a direct effect on biochemical reaction kinetics in poikilothermic marine invertebrates, thereby affecting a broad spectrum of processes ranging from cellular metabolism to behaviour of the organism (Kinne 1970, Mangum et al. 1972). The effect of temperature on gelatinous zooplankton has been studied for different species with respect to respiration (Kremer 1977), swim beat frequency (Gatz et al. 1973) and prey capture (Olesen 1995). However, the effect of temperature on growth of gelatinous zooplankton is largely unknown.

Temperature has been suggested to affect growth of the scyphozoan jellyfish Aurelia aurita in different ways. In the Skagerrak and the southern Baltic, growth of $A$. aurita can be divided into 3 phases: (1) A. aurita reside in deep waters as ephyrae without any net

\footnotetext{
•E-mail: 1.j.hansson@kmf.gu.se
}

growth for several months. (2) In spring, exponential growth is initiated and the medusae continue to grow until (3) they are full-grown in the summer and a final average medusa size is reached (Möller 1980, Hernroth \& Gröndahl 1985). These boreal coastal regions are characterized by large seasonal fluctuations in temperature of the surface water, which varies from around $0^{\circ} \mathrm{C}$ in winter to about $20^{\circ} \mathrm{C}$ in summer. Möller (1980) suggested that start of growth in spring may be water-temperature-dependent, possibly through a temperature mediated increase in standing stock of copepods. Initiation of medusa growth may, thus, change from year to year in response to inter-annual temperature variations.

Based on field observations of Aurelia aurita from the Kiel Bight, Schneider \& Behrends (1994) suggested abundance of medusae and competition for food to be the main factors governing the final size of medusae, with temperature inducing some minor variations. However, not many studies describe the effect of temperature on the growth phase. One reason for this may 
be that, in the field, several envirommental factors beside temperature change over time and the effect of temperature may, thus, be obscured. Furthermore, gelatinous zooplankton are difficult to keep in good condition for longer periods in the laboratory, obstructing long-time experiments on growth. The aim of this study was to quantify the effect of temperature on growth rate of non-food-limited $A$. aurita medusae in the laboratory and to compare these results with field data.

\section{MATERIAL AND METHODS}

Growth of Aurelia aurita, kept in water of different temperatures in the laboratory, was followed daily in mid June 1996. Medusae were collected from surface water $\left(14^{\circ} \mathrm{C}, 26 \% \mathrm{~S}\right)$ in Gullmarsfjorden, Sweden. I hey were caught in buckets and touched as little as possible. Within 10 min the medusae were brought to the laboratory, where each specimen was put in one of four $20 \mathrm{l}$ glass aquaria. Water temperature in the four aquaria was siowiy (approximately $1^{\circ} \mathrm{C} \mathrm{h}^{-i}$ ) changed to $5.1,10.0,16.4$ and $19.0^{\circ} \mathrm{C}$, respectively, by placing the aquaria in different thermoconstancy rooms. Water temperature was measured twice per day and remained stable $\left(\mathrm{SD}=0.3^{\circ} \mathrm{C}\right.$ ) throughout the experiment. Acclimation time to temperature changes has been estimated for another scyphozoan medusa to be a few hours (Gatz et al. 1973). After 36 h acclimation, $A$. aurita that appeared to be in good condition (a subjective judgement based on the criteria that the medusa should have powerful swim beats in an even rhythm and no visible damage on umbrella or tentacles) were chosen and each medusa was transferred to a separate white polythene bucket filled with 10 I surface water,

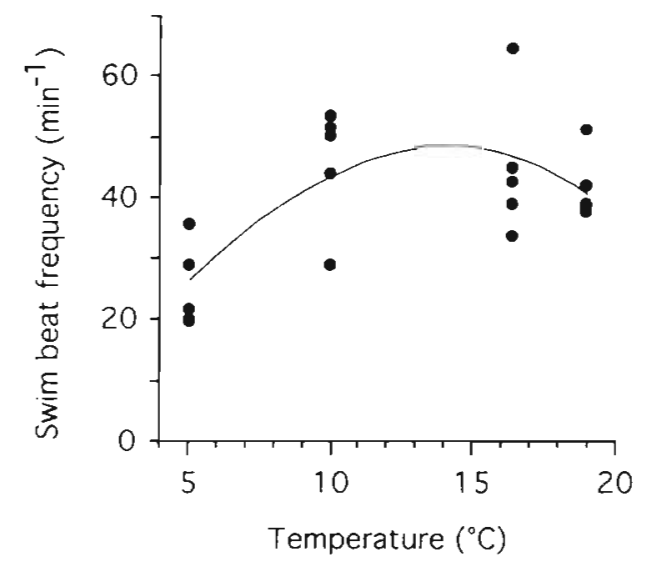

Fig. 1 Aurelia aurita. Swim beat frequency of jellyfish at 4 temperatures in the laboratory. Curve fitted from a 3rd-order polynomial at the respective temperature, containing a high concentration of zooplankton. After another 20 h the size of each $A$. aurita was measured as described below, and this denoted the start of the experiment.

Size of medusae in the experiment ranged from 40.8 to $96.4 \mathrm{~mm}$ diameter. No difference in initial size between the 4 treatment groups was detected ( $p$ > $0.05,1$-factor ANOVA, $n=5$ ). According to the sizedependent clearance rate given by Olesen (1995) these medusae would display a clearance rate ranging from 1.3 to $7.2 \mathrm{l} \mathrm{h}^{-1}$, equivalent to zooplankton mean residence times $\left(t_{1 / 2}\right)$ of 5 and 1 h respectively. Swim beat frequency of the medusae was recorded once per day by counting number of swim pulses during $1 \mathrm{~min}$, or at least 50 pulses (Fig. 1).

Size of medusae was measured, as described below, once per day for $4 \mathrm{~d}$. After each daily size measurement, half of the water in the bucket was replaced with new, temperalure-adjusted water and a concentrated suspension of zooplankton was added. Plankton used as food was collected daily from Gullmarsfjorden with a $250 \mu \mathrm{m}$ plankton net. For each medusa a $300 \mathrm{ml} \mathrm{sam-}$ ple was taken from this concentrated suspension of zooplankton. The sample was then filtered through a $1 \mathrm{~mm}$ plankton gauze to remove hydrozoans, ctenophores and large aggregates and gradually acclimated to 1 of the 4 treatment temperatures before it was added to the bucket with medusa. Three samples from the zooplankton suspension were preserved in $4 \%$ formaldehyde for later analyses of composition and number of prey (Fig. 2).

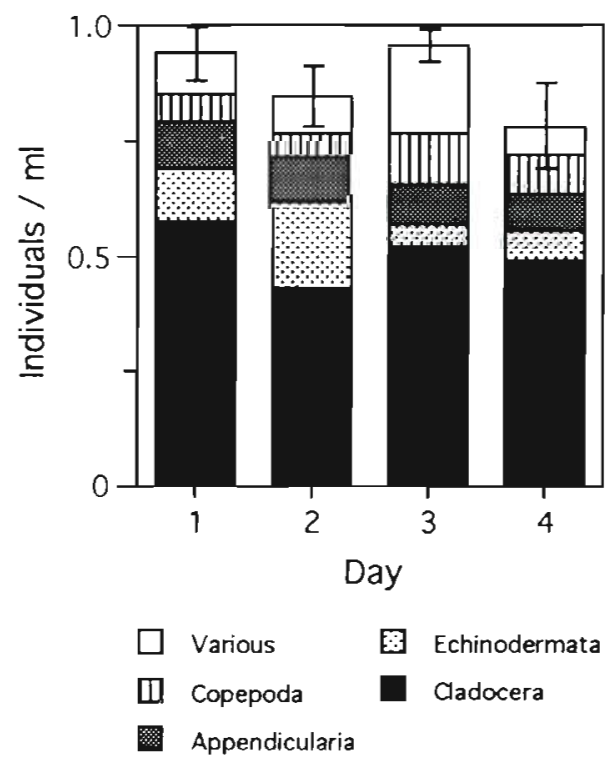

Fig. 2. Average initial concentration and composition of prey in buckets containing 1 Aurelia aurita 40.8 to $96.4 \mathrm{~mm}$ diameter) and $10 \mathrm{l}$ water. Estimate from 3 subsamples taken each day. Error bars $=\mathrm{SD}$ 
Initial food concentrations during the incubations were several times higher than the concentration normally found in the field (Eriksson 1973) and the groups Cladocera, Appendicularia and Copepoda

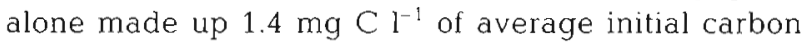
content in the buckets. Based on the zooplankton left in the bucket after the last day of incubation, a rough estimate of consumption and clearance rate was made on 1 medusa from each temperature group. It was assumed that zooplankton were evenly distributed in the bucket when half of the water was replaced Average consumption rate was 1900 ind. Aurelia aurita $^{-1} \mathrm{~d}^{-1}$. Consumption of the groups Cladocera, Appendicularia and Copepoda alone made up $2.4 \mathrm{mg}$ C A. aurita ${ }^{-1} \mathrm{~d}^{-1}$. Clearance rates varied amongst prey from $0.2 \mathrm{l}$ A. aurita ${ }^{-1} \mathrm{~d}^{-1}$ for Cladocera to $7.01 \mathrm{~A}$. aurita ${ }^{-1} \mathrm{~d}^{-1}$ for Appendicularia, possibly reflecting prey selection by $A$. aurita or different prey reproduction rates. Average clearance rate was $2.21 \mathrm{~A}$. aurita ${ }^{-1}$ $\mathrm{d}^{-1}\left(t_{1 / 2}=76 \mathrm{~h}\right)$, and thus, after each day of incubation, approximately $80 \%$ of initial prey concentration was not consumed by $A$. aurita. Throughout the experiment, light was kept low and dim. Mean water salinity over time of the experiment was $25.9 \%$ and average oxygen concentration in the buckets declined $7 \%$ in $1 \mathrm{~d}$.

Size measurements of medusae. Medusae were taken from the buckets in a glass petri dish with a small amount of water. The petri dish was placed on a semi-transparent mm grid. With their oral side upwards the medusae were lit from below through the grid, and their silhouette was video recorded. The area inside the fringe of tentacles (subumbrellar area) was later measured by image analysis, using the software NIH Image 1.55. Medusae continued to pulsate in the petri dish and the subumbrellar areas were measured when the medusae were in their most relaxed state. Precision of the method was tested by alternately recording 2 differently sized medusae. This was repeated 10 times at 5 min intervals and the diameters and subumbrellar areas were subsequently measured (Table 1). Precision of the measurements was fairly high, with standard deviation being approximately $1 \%$ of the mean size estimate for those 10 repeated measurements. Precision was equally good for measurements of area and diameter. However, by using area measurements, smaller (approximately 50\%) daily growth could be detected compared to measurements of diameter. The technique of video imaging for size measurements thus appears promising and opens possibilities for estimating growth of several species of oblate scyphozoan and hydrozoan medusae in shortterm laboratory experiments.

Conversion factors were estimated to translate area measurement into medusan diameter and diameter into biomass of the jellyfish. Distance between 2 opposite rhopalia was measured (average of interradial and perradial diameter) and used as diameter to calculate the area of a circle $\left(A_{c}, \mathrm{~mm}^{2}\right\}$. However, since a medusa is not perfectly circular, this calculated area was related to the measured area $\left(A_{m}, \mathrm{~mm}^{2}\right)$ by linear regression. $A_{c}$ was linearly related to $A_{m}$ by the equation:

$$
A_{c}=0.947 A_{m}+64.069\left(n=35, r^{2}=0.999\right)
$$

Diameter $(D, \mathrm{~mm})$ of a medusa could thus be calculated from $A_{\mathrm{m}}$ as:

$$
D=2\left[\left(0.947 A_{m}+64.069\right) / \pi\right]^{0.5}
$$

To estimate wet weights of Aurelia aurita of different sizes, medusae (12 to $310 \mathrm{~mm}$ diameter) were placed on a plastic net ( $1 \mathrm{~mm}$ mesh size) over a paper towel to let excess water run off for approximately $5 \mathrm{~s}$ and thereafter weighed. Diameters of the same specimens were measured, and the relation between diameter and wet weight was calculated using linear regression of the log-log plot. Wet weight ( $w w, g$ ) of a medusa was related to $D$ as:

$$
W W=10^{-4.63} D^{3.092}\left(n=44, r^{2}=0.994\right)
$$

The high coefficients of determination in Eqs. (1) \& (3) indicate that not much variation was introduced into the data when wet weight was calculated from medsured area or diameter.

For each medusa, specific growth rate was estimated from the calculated change in wet weight from the equation:

$$
G=\Delta \ln w w(\Delta t)^{-1}
$$

Table 1 Precision of 10 repeated size measurements on 2 specimens of Aurelia aurita. Daily growth of the medusae was calculated using specific growth rate $=0.1 \mathrm{~d}^{-1}$ to demonstrate the stronger signal obtained when using area instead of diameter as variable when estumating size

\begin{tabular}{|lccc|}
\hline & $\begin{array}{c}\text { Medusa } \\
\text { no. }\end{array}$ & $\begin{array}{c}\text { Area } \\
\left(\mathrm{mm}^{2}\right)\end{array}$ & $\begin{array}{c}\text { Diameter } \\
(\mathrm{mm})\end{array}$ \\
\hline Mean size & 1 & 2436 & 55.1 \\
Coefficient of varlation (\%) & 2 & 6675 & 90.7 \\
& 1 & 1.1 & 1.1 \\
Range of estimates (\% deviation from mean) & \\
Lowest estimate & 2 & 1.0 & 1.3 \\
& 2 & 2.2 & 1.7 \\
Highest estimate & 1 & 1.6 & 1.8 \\
& 2 & 1.0 & 2.0 \\
Daily growth signal if specific growth rate $=0.1 \mathrm{~d}^{-1}$ & 3.3 \\
(\% of initial mean size) & 1 & 6.9 & 3.3 \\
& 2 & 6.7 & 3.3 \\
\hline
\end{tabular}




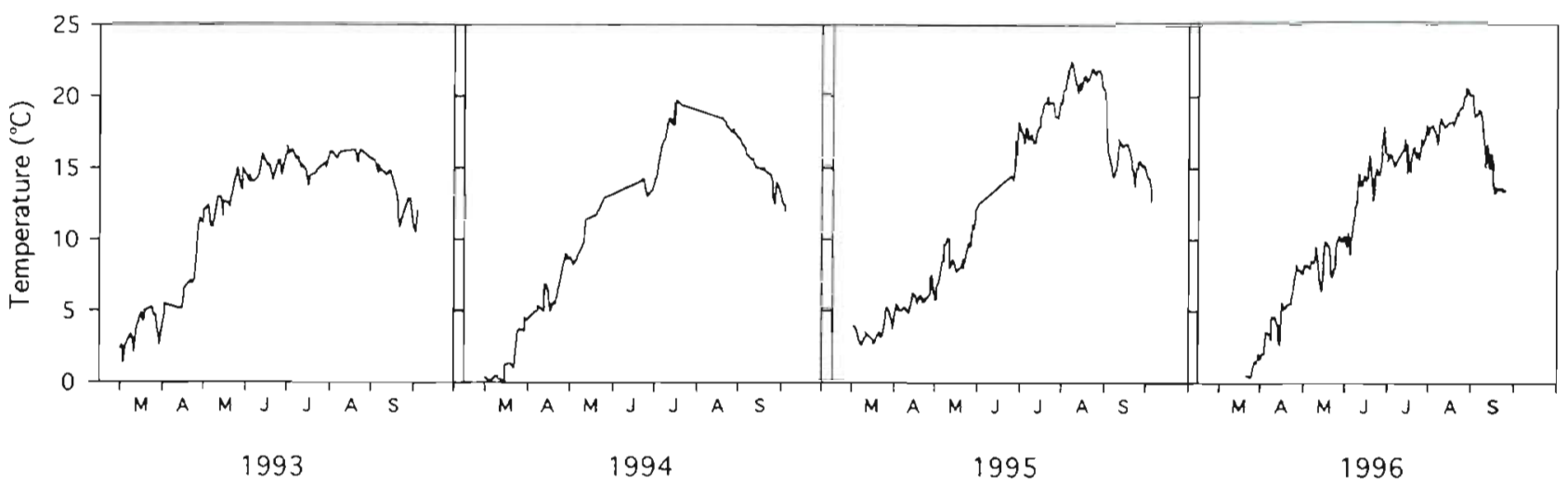

Fig. 3. Temperature of the surface water (at $1 \mathrm{~m}$ depth) of Gullmarsfjorden, Sweden

where $G$ is daily specific growth rate $\left(\mathrm{d}^{-1}\right)$ and $\Delta \mathrm{In}$ $w w$ is change in natural logarithm of wet weight over the time intervai $\Delta t$. $G$ was calculated from the slope of regression lines for the $4 \mathrm{~d}$ of data on values of $\ln w w$ over time. Difference in daily specific growth rate between the 4 temperature groups was tested in a 1-factor ÂNO' $\mathrm{n}=5$ ) after the data were tested with Cochran's test for homogeneity of variances (significance level 0.05) and shown to meet the requirements of homoscedasticity.

Field data. Values of $G$ found in the laboratory were compared to specific growth rate of medusae in the field' $\left(G_{f}, d^{-1}\right)$. Sizes of medusae of Aurelia aurita sampled in the western part of Gullmarsfjorden were followed through the summer from 1993 to 1996 . Jellyfish were caught in the surface water $(0$ to $2 \mathrm{~m})$ with a $1000 \mu \mathrm{m}$ plankton net or a landing net. Diameter of medusae was measured with a mm scale and oral arms were inspected for presence of planula larvae. On average, 72 medusae were measured per sampling occasion (a total of 3248 medusae). The diameter of each medusa was then translated to wet weight by Eq. (3). The natural logarithms of these weight values were plotted over time. For each year, 2 linear regressions were fitted to the data. one for the exponential growth phase (slope $=G_{f}$ ) and one for the plateau phase. To select the time interval for each of the regressions, as many days of data were included in each of the 2 regression lines as were required to minimize the total mean squares of the residual. The intersection of the regression lines will then indicate the time when net somatic growth of $A$. aurita ceases. To calculate $G_{\mathrm{f}}$ from in situ size measurements of $A$. aurita over time, the assumption of no size-selective mortality has to be made. Physical damage of medusae caused by strong winds and predation by other cnidaria, such as Cyanea capillata and Metridium senile, probably cause most deaths of jellyfish in the study area during spring. None of these are known to cause size-selective mortality.

To compare laboratory estimates of growth rate with field data, $G_{f}$ for the field population was compared to the theoretical growth of a non-starved medusa, based on daily ambient surface water temperature and laboratory estimates of temperature-specific growth rate. The exponential growth phase in the field covers a wide range of medusa sizes. To reduce extrapolation of laboratory results to medusa sizes outside those investigated in the experiment, a restricted daily specific growth rate $\left(G_{f^{*}}, \mathrm{~d}^{-1}\right)$ for Aurelia aurita in the field was calculated. This was solely based on sampling dates when estimated average wet weight $\pm \mathrm{SD}$ overlapped the weight range of medusae used in the laboratory experiment (i.e. 2.24 to $32.0 \mathrm{~g}$ wet weight). $G_{f}$ was calculated from the slope of these regression lines, similar to the calculation of $G$ for medusae in the laboratory. For each year, the trajectory of size over time was constructed for a non-starved theoretical medusa, of same initial size as average ln wet weight of the field population, by entering daily surface water temperature into laboratory derived Eq. (5) (see below). Growth rate was calculated from the regression line of growth of this theoretical medusa. The difference between the slope of this regression line and that from field observations was tested according to Fowler \& Cohen (1990). Temperature of the surface water was measured almost daily (08:00 to 08:30 h) at Kristineberg Marine Research Station, i.e. in the area where the medusae were collected (Fig. 3)

\section{RESULTS}

Area of the subumbrella increased over time during the experiment. Average daily percentage increase of the subumbrellar area ranged from 2.8 to $11.1 \%$, 


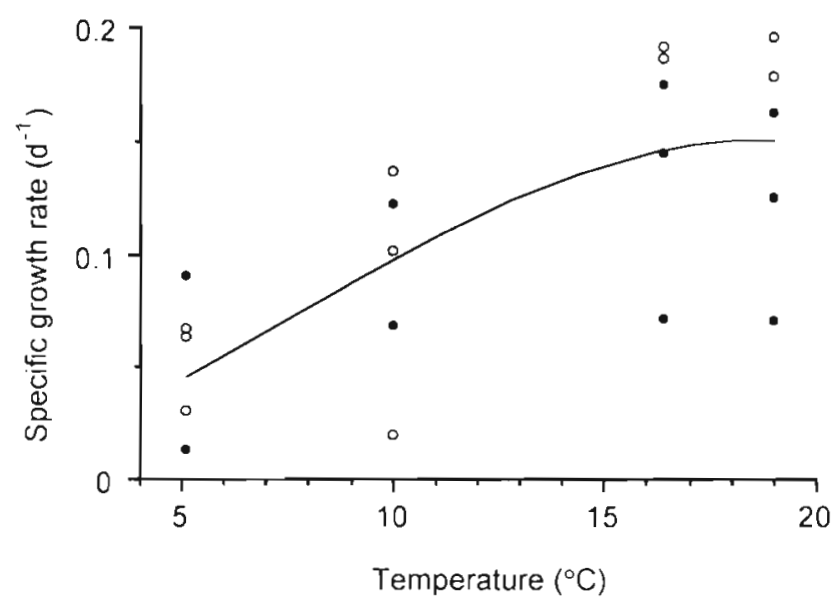

Fig. 4. Aurella aurita. Daily specific growth rate of jellyfish (40.8 to $96.4 \mathrm{~mm}$ diameter) at 4 temperatures in the laboratory. Open circles: 40 to $70 \mathrm{~mm}$ diameter; filled circles: 70 to $100 \mathrm{~mm}$ diameter

which is several times higher than the estimated coefficient of variation for the method as calculated above (Table 1). Precision of the method thus seemed adequate for daily growth determinations.

Daily specific growth rate $\left(G, \mathrm{~d}^{-1}\right)$ differed significantly among the treatment groups $(p=0.0022, F=$ 7.62, df $=3,16 ; 1$-factor ANOVA), indicating that growth of Aurelia aurita was temperature dependent (Fig. 4). Overall, $G$ increased with temperature (significant regression, $\mathrm{p}<0.05)$. Of the 4 temperatures $(T$, ${ }^{\circ} \mathrm{C}$ ) investigated, average $\mathrm{G}$ was highest at $16.4^{\circ} \mathrm{C}$. Data were interpolated by use of a 3rd-order polynomial curve fit. The equation for the resultant curve was

$$
\begin{gathered}
G=-2.5 \times 10^{-5} \mathrm{~T}^{3}+5.2 \times 10^{-4} \mathrm{~T}^{2}+7.1 \times 10^{-3} \mathrm{~T} \\
\left(\mathrm{r}^{2}=0.502\right)
\end{gathered}
$$

Growth curves from Gullmarsfjorden for the 4 years revealed that growth rate decreased slowly over time until there was an abrupt stop in net growth (Fig. 5). Time when growth ceased was in most years close to the time when $10 \%$ of Aurelia aurita carried visible planula larvae on their oral arms. This may be an indication that energy was directed from somatic growth to reproduction. $G_{f}$ for 1993 to 1996 was $0.18,0.13,0.11$ and $1.16 \mathrm{~d}^{-1}$.

Theoretical growth rate, based on the laboratoryderived growth-temperature relationship, was significantly different from observed $G_{1}{ }^{\circ}(p<0.05)$ in 1993 and 1994, but no difference was detected in 1995 and 1996 (Fig 6). Since observed $G_{i}^{*}$ was similar to or higher than $G$ based on laboratory estimates for medusae with excess food, Aurelia aurita may not have been food limited during spring in Gullmarsfjorden. All regressions of exponential growth phases were significant $(\mathrm{p}<0.05)$.

\section{DISCUSSION}

The laboratory experiment indicates a net increase in weight-specific growth rate, $G$, with increasing water temperature. If food demands of the medusae are met in the field, a higher growth rate during spring and early summer may therefore be expected in years with high water temperature compared to cold years. Since predation pressure exerted by Aurelia aurita is related to size of the medusa (Bailey \& Batty 1983, 1984, Olesen 1995) temperature may therefore be a factor regulating predation pressure on mesozooplankton in spring. The shape of the experimentally derived curve of growth rate versus temperature (Fig. 4) closely resembles the temperature response curve for swim pulse frequency of $A$. aurita from the same latitude (Thill 1937, Olesen 1995) (Fig. 1) Since A. aurita capture prey entrained in currents created by swim propulsion activity (Costello \& Colin 1994), it is possible that the observed temperature-dependent growth was caused by variations in predation rate due to the temperature-dependent swimming activity. It may be speculated that, for consumption of prey, the high potential encounter rate (due to high prey concentration) between predator and prey in the experiment would have superseded the effect of medusa swimming activity. However, consumption rate depends not merely on encounter, but involves processes such as successful capture and transportation to the gastral cavities. The effect of swimming activity on these processes is not known.

Specific growth rates estimated from field data $\left(G_{i}{ }^{*}\right)$ ranged from 0.11 to $0.16 \mathrm{~d}^{-1}$, which was similar to or even higher than expected from laboratory experiments (Fig. 6), indicating either that growth of Aurelia aurita was not food limited during spring in Gullmarsfjorden or that growth was inhibited in the laboratory. Substantially higher growth rates than those estimated in this study have been reported elsewhere. Olesen et al. (1994) estimated specific growth rate of a nonstarved medusa ( $4 \mathrm{~mm}$ initial diameter) in the laboratory at $0.22 \mathrm{~d}^{-1}$ Growth rates of field populations of medusae can also be calculated from literature data. In the Kiel Bight, maximal growth rate of $A$. aurita was $0.11 \mathrm{~d}^{-1}$ according to data presented by Schneider (1989). Hernroth \& Gröndahl (1983) reported a maximum growth rate (based on population average diameter) of $A$ aurita ( $5 \mathrm{~mm}$ initial average diameter) from Gullmarsfjorden corresponding to $0.25 \mathrm{~d}^{-1}$. Lucas \& Williams (1994) found a maximum instantaneous specific growth rate of $0.31 \mathrm{~d}^{-1}$ (this was also based on population average diameter).

However, it is important to be careful when comparing data obtained in different ways or on animals of different size. Calculations of instantaneous specific 


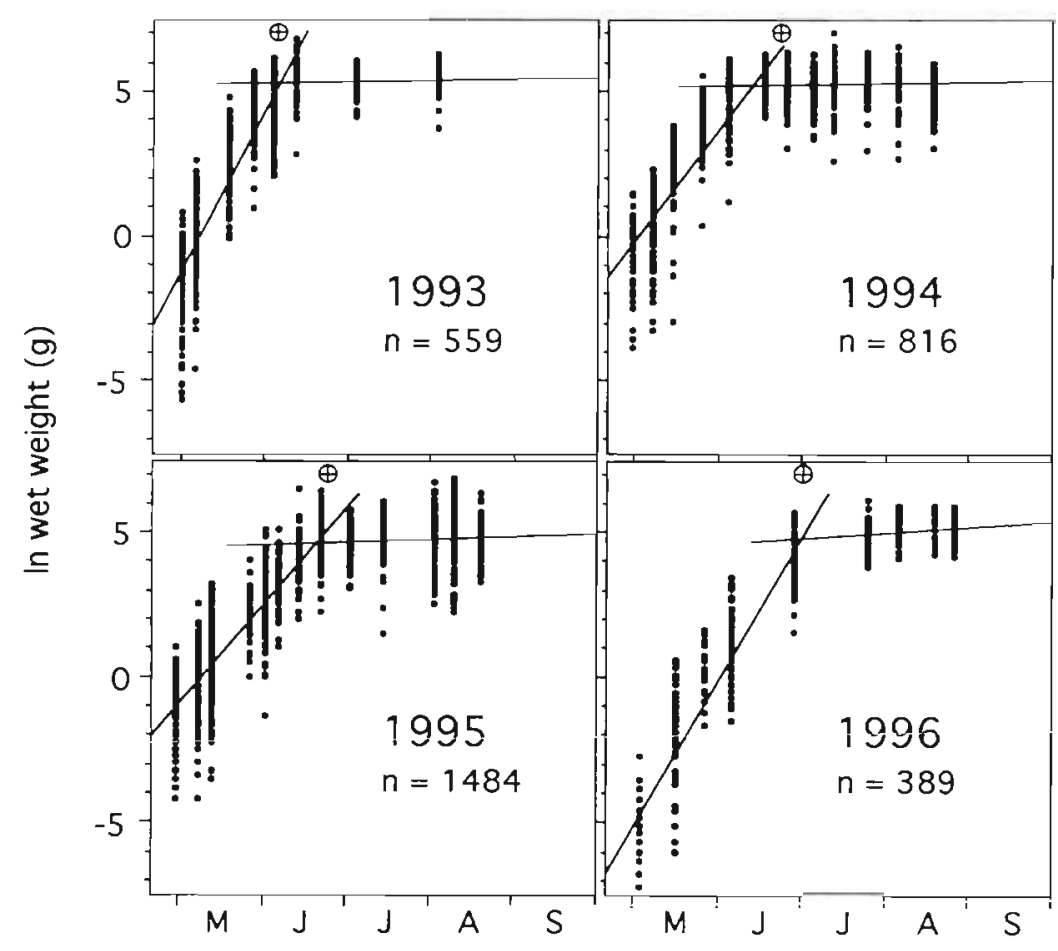

Fig. 5. Aurelia aurita. Weight of individual medusae sampled in Gullmarsfjorden over summer, 1993 to 1996 . Two linear regressions were fitted to the data. $\mathrm{n}=$ total number of medusae. Circle with cross inside denotes time when $10 \%$ of medusae carried planula larvae on their oral arms

ature (Ikeda 1985). When growth rate data from the literature presented above and from this study are related to medusa size, the specific growth rate of Aurelia aurita appears to decrease with size (linear regression, $p<0.05$, data excluded when specific growth rate $<$ $0.05 \mathrm{~d}^{-1}$ to eliminate the accumulation of data points from non-growing adult medusae) (Fig. 7). Reduced somatic growth rate with medusa size may be caused by starvation, shunting of energy to gamete production or a genetically determined cessation of growth (as discussed below). In this study, the effect of size on growth rate results was reduced by comparing growth rates of medusae within the same size interval.

There was some uncertainty in the field estimates of temperature experienced by medusae. Temperature was measured at $1 \mathrm{~m}$ depth in the morning, when water is colder than average daily temperature. However, morning temperature did not deviate more than approximately $2^{\circ} \mathrm{C}$ from daily maximum temperature (investigated in 1995 and 1996). The water in Gullmarsfjorden is stratified, with surface water

growth rate from average body size within a population over time does not give independent values; the accuracy of a size estimate at one sampling occasion affects the estimate of instantaneous specific growth rate for both the preceding and the succeeding time interval. This dependency of data is avoided when specific growth rate is calculated from regression of all data. Furthermore, metabolic rates of marine zooplankton are a function of both body mass and temper- extending down to a depth of approximately $15 \mathrm{~m}$ (Lindahl \& Hernroth 1983), and during the medusa season, Aurelia aurita is almost exclusively found in the surface water (author's pers. obs.). Usually the temperature of this water declines with depth, and medusae may have experienced warmer water above and colder water below $1 \mathrm{~m}$ depth, where the temperature was measured. Furthermore, there is considerable surface water exchange in Gullmarsfjorden, both with the

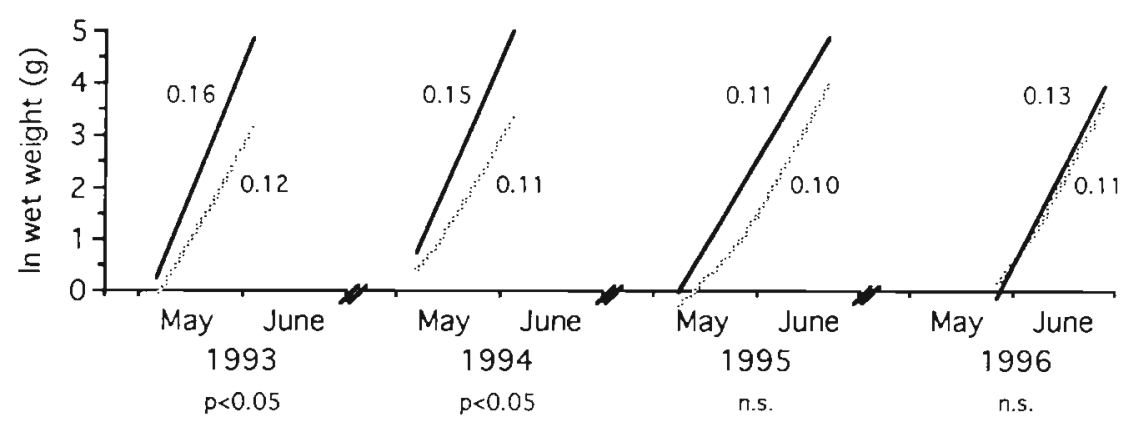

Fig. 6. Aurelia aurita. Size of jellyfish over the time interval when average wet weight \pm SD of medusae in Gullmarsfjorden overlapped 2.24 to $32.0 \mathrm{~g}$ (weight range of medusae in experiment). Estimated size of medusae in situ indicated by black line. Grey line indicates calculated size of a medusa based on daily temperature in the fjord and laboratory-denved relation between temperature and growth rate. Daily specific growth rate $\left(\mathrm{d}^{-1}\right)$ for each line included. Differences between observed and calculated growth rates were tested according to Fowler \& Cohen (1990) and results are noted below each year. n s. not significant at p < 0.05 


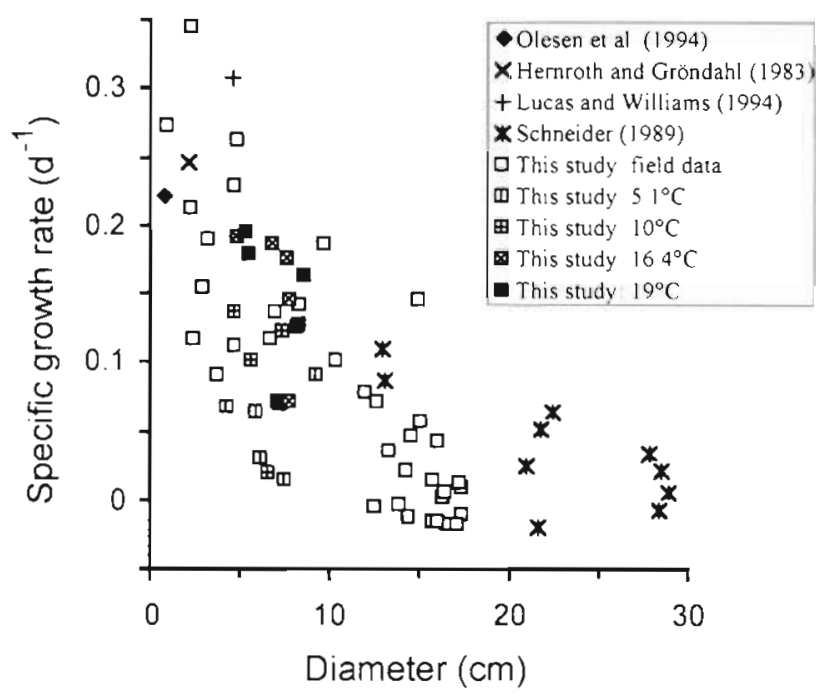

Fig. 7 Aurelia aurita. Literature data on growth rate of jellyfish of different size. Data from Olesen et al. (1994) and growth rate estimates at specific temperatures from this study are based on laboratory measurements of individual medusae. The other data sets display instantaneous specific growth rates. Diameter for these was calculated from average ln wet weight for each pair of measurements

open sea and with the inner fjord systems, and the sampled medusae probably belong to the same coastal population. The observed medusae may thus have been transported from other areas along the coast, where temperature and food regimes were different to those in the fjord.

Another explanation for the high values of $G_{f}$ in the field compared to laboratory estimates may be that the experimental conditions to some degree inhibited growth in the laboratory. Gelatinous zooplankton are often large and sensitive, and the laboratory environment may subject the organisms to a variety of stress factors. One of the most obvious may be the effect of container volume, which can affect processes such as predation rate and prey selection (de Lafontaine \& Legget 1987. Toonen \& Chia 1993). Medusae in the experiment were frequently observed to swim against the walls or bottom of buckets. Any disturbance of the organism as a result of the video recording procedure is likely to have been small, since daily handling time of the organism was short. It only took a few minutes to bring the jellyfish to the video camera, record its subumbrellar area and put it back into the water. Since the exumbrella rested against a flat glass surface surrounded by water, physical disturbances due to touching were probably of minor importance for growth. It is possible that Aurelia aurita is dependent on a continuous, natural concentration of zooplankton for maximum growth. Initial carbon concentration of zooplankton in the experiment was approximately an order of magnitude higher than natural average concentration (author's pers. obs., June 1995). The medusae may have directed part of their energy to emitting undigested food items, and this may have reduced growth rate in the experiment. Further experimental studies are needed to elucidate the relative effects of the factors temperature, prey concentration and medusa size on growth rate of jellyfish. Growth rates of differently sized $A$. aurita may e.g. be measured at their optimal zooplankton concentration.

Food limitation has been suggested as a determinant of final medusa size in summer (Olesen et al. 1994, Schneider \& Behrends 1994). If medusae continued to grow at the high in situ growth rates estimated from exponential growth phases, food demand would at some point exceed the supply. It is possible to estimate when this would occur by comparing in situ food (carbon) concentration with the concentration needed to satisfy the carbon needs of Aurelia aurita growing at estimated in situ spring growth rates.

Daily food requirements were calculated as costs of growth+respiration+excretion divided by assimilation efficiency. Daily growth was calculated as the difference in weight between 2 consecutive days. Weight of medusae was estimated from in situ growth rates starting at the same date as for the data in Fig 6. Wet weights ( $w w, g)$ were converted to carbon content (C, mg) as:

$$
C=0.867 w w+20.85
$$

(Schneider 1988a) and respiration $\left(R, \mu l \mathrm{O}_{2} \mathrm{~h}^{-1}\right)$ from dry weight ( $d w, \mathrm{mg}$ ) according to Larson (1987):

$$
R=0.2 d w
$$

$d w$ was derived from diameter $(D, \mathrm{~mm})$ following Olesen et al. (1994):

$$
d w=0.00173 D^{282}
$$

where $D$ was calculated from Eq. (3). Respiration was converted to carbon by assuming a respiratory quotient of 0.8 (protein dominated metabolism) (Larson 1987). Carbon excretion was assumed to be $1.2 \mathrm{mg}$ carbon $\mathrm{d}^{-1}$ irrespective of medusan size (Hansson \& Norrman 1995). An assimilation efficiency of $85 \%$ was assumed. Prey concentration needed was calculated by dividing daily carbon need by clearance rate $(F, \mathrm{ml}$ $\mathrm{h}^{-1}$ ) of individual Aurelia aurita, which has been related to cross sectional area $\left(A, \mathrm{~mm}^{2}\right)$ of the medusae by Olesen (1995) as:

$$
F=1.08 \mathrm{~A}-73.05
$$

for 3.2 to $46.3 \mathrm{~mm}$ diameter medusae feeding on the rotifer Brachionus plicatilis and on the copepod Acartia tonsa. This clearance rate was also assumed valid for larger medusae and other prey. 


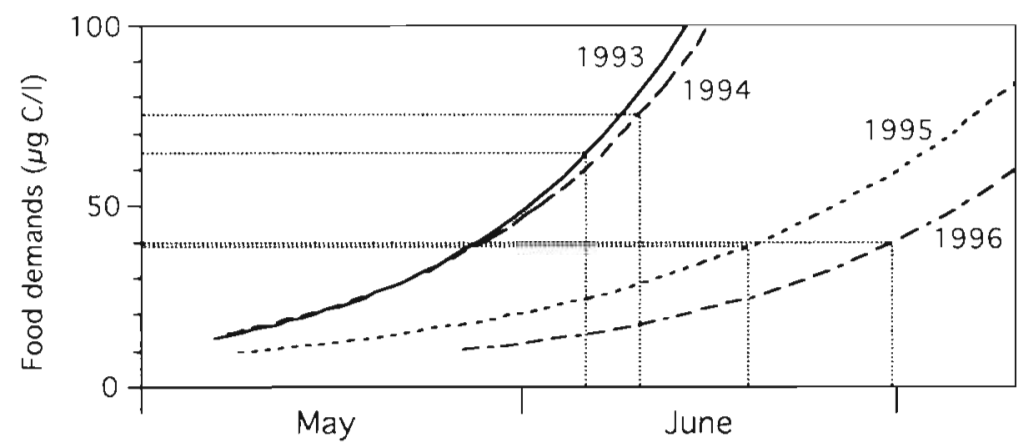

Calculated food concentration needed at the time when net growth of medusae ceased ranges from 39 to $75 \mu \mathrm{g} \mathrm{Cl}^{-1}$ (Fig. 8). Natural concentrations of medusan food were not monitored during these $4 \mathrm{yr}$, and there does not appear to be much literature data for the surface water of this area. However, in May 1987 average biomass of mesozooplankton was estimated to be 10 and $29 \mu \mathrm{g} \mathrm{C} \mathrm{l}^{-1}$ respectively at 2 locations in the open Skagerrak (Rosenberg et al. 1990). In June 1995 concentration of mesozooplankton in the surface water of Gullmarsfjorden was estimated at almost $300 \mu \mathrm{g} \mathrm{C} \mathrm{l}^{-1}$ (author's pers. obs.). These numbers are quite different, with estimated critical-food-demand concentrations in between, indicating that the exponential growth of Aurelia aurita may have stopped as a result of food shortage. However, without accurate measurements of prey concentration over time, this cannot be ascertained.

There was a close fit between the time when $10 \%$ of the medusae carried planula larvae on their oral arms and estimated time when Aurelia aurita reached maximum size (Fig. 5). The cost of producing planula larvae was not included in Fig. 8 but probably further increases food demand of the medusae. Planula larvae appear to be lecithotrophic until they settle (Widersten 1968) and their production would thereby involve an energetic cost for the mother

Cessation in somatic growth may also be genetically determined. Number of planula larvae is correlated with size of the female medusa (Schneider 1988b), and if reproductive success increases with number of larvae produced, large female size at the time of reproduction would be favored, whereas there may be no selective pressure for growth of the adult after reproduction, since there is no parental care after release of planula larvae. Aurelia aurita may then stop growing after reproduction, independently of food supply.

Acknowledgements. This study was supported by the Marine Research Centre, Göteborg University and by the Swedish Natural Science Research Council (contract to R. Rosenberg). $I$ thank Peter Tiselius and Rutger Rosenberg for constructive comments on the manuscript. $93-100$
Fig. 8. Aurelia aurita. Calculated concentrations of food (carbon) needed to support jellyfish continuously growing at specific growth rates estimated from in situ observations. Dotted lines intersect with curves at time when exponential growth phases of medusae from Gullmarsfjorden were observed to have stopped

\section{LITERATURE CITED}

Balley KM, Batty RS (1983) A laboratory study of predation by Aurelia aurita on larval herring (Clupea harengus): experimental observations compared with model predictions. Mát Biol 72:295-301

Balley KM, Batty RS (1984) Laboratory study of predation by Aurelia aurita on larvae of cod, flounder, plaice and herring: development and vulnerability to capture. Mar Biol $83: 287-291$

Costello Ir I, Colin SP (1994) iviutpinuluyy, filutd motion and predation by the scyphomedusa Aurelia aurita. Mar Biol $121: 327-334$

de Lafontaine $Y$, Legget WC (1987) Effect of contanner size on estimates of mortality and predation rates in experiments with macrozooplankton and larval fish. Can J Fish Aquat Sci 44:1534-1543

Eriksson S (1973) Abundance and composition of zooplankton on the west coast of Sweden. Zoon 1:113-123

Fowler J, Cohen L (1990) Practical statistics for field biology John Wiley \& Sons, Chichester

Gatz AJ Jr, Kennedy VS, Mihursky JA (1973) Effects of temperature on activity and mortality of the scyphozoan medusa Chrysaora quinquecirma. Chesapeake Sci 3:171-180

Hansson LJ, Norrman B (1995) Release of dissolved organic carbon (DOC) by the scyphozoan jellyfish Aurelia aurita and its potential influence on the production of planktic bacteria. Mar Biol 121:527-532

Hernroth L, Gröndahl F (1983) On the biology of Aurella aurita (L.) 1 Release and growth of Aurelia aurita (L.) ephyrae in the Gullmar Fjord, western Sweden, 1982-83 Ophelia 22:189-199

Hernroth L, Gröndahl F (1985) On the biology of Aurelia aurita (L.): 2. Major factors regulating the occurrence of ephyrae and young medusae in the Gullmar Fjord, western Sweden. Bull Mar Sc1 37:567-576

Ikeda $\mathrm{T}$ (1985) Metabolic rates of epipelagic marine 200plankton as a function of body mass and temperature. Mar Biol 85:1-11

Kinne $O(1970)$ Temperature. Invertebrates. In: Kinne $O$ (ed) Marine ecology. A comprehensive, integrated treatise on life in oceans and coastal waters, Vol 1, Environmental factors, Part 1 Wiley-Interscience, London, p 407-514

Kremer P (1977) Respuration and excretion by the ctenophore Mnepiopsis leidyl. Mar Biol 44:43-50

Larson RJ (1987) Respiration and carbon turnover rates of medusae from the NE Pacific. Comp Biochem Physiol 87 A:

Lindahl O. Hernroth L (1983) Phyto-zooplankton community in coastal waters of western Sweden-an ecosystem off balance? Mar Ecol Prog Ser 10:119-126 
Lucas $\mathrm{CH}$, Williams JA (1994) Population dynamics of the scyphomedusa Aurelia aurita in Southampton Water. J Plankton Res 16:879-895

Mangum CP, Oakes MJ, Shick JM (1972) Rate-temperature responses in scyphozoan medusae and polyps. Mar Biol 15:298-303

Möller $H$ (1980) Population dynamics of Aurelia aurita medusae in the Kiel Bight, Germany (FRG). Mar Biol 60: $123-128$

Olesen NJ (1995) Clearance potential of jellyfish Aurelia aurita, and predation impact on zooplankton in a shallow cove. Mar Ecol Prog Ser 124:63-72

Olesen NJ, Frandsen K, Risgârd HU (1994) Population dynamics, growth and energetics of jellyfish Aurelia aurita in a shallow fjord. Mar Ecol Prog Ser 105:9-18

Rosenberg R, Dahl E, Edler L, Fyrberg L, Granéli E, Granélı W. Hagström A, Lindahl O, Matos MO, Pettersson $K$, Sahlsten E, Tiselius P. Turk V. Wikner J (1990) Pelagic nutrient and energy transfer during spring in the open and coastal Skagerrak. Mar Ecol Prog Ser 61:215-231

Editorial responsibility: Otto Kinne (Editor),

Oldendorf/Luhe, Germany
Schneider G (1988a) Chemische Zusammensetzung und Biomasseparameter der Ohrenqualle Aurelia aurita. Helgol Meeresunters 42:319-327

Schneider G (1988b) Larvae production of the common jellyfish Aurelıa aurita in the Western Baltic 1982-1984. Kieler Meeresforsch 6:295-300

Schneider G (1989) Estimation of food demands of Aurelia aurita medusae populations in the Kiel Bight/western Baltic. Ophelia 31:17-27

Schneider G, Behrends G (1994) Population dynamics and the trophic role of Aurelia aurita medusae in the Kiel Bight and western Baltic. ICES J Mar Sci 51:359-367

Thill H (1937) Beiträge: zur Kenntnis der Aurelia aurita (L.). Z Wiss Zool 150:51-96

Toonen RJ, Chia F (1993) Limitations of laboratory assessments of coelenterate predation: container effects on the prey selection of the Limnomedusa, Proboscidactyla flavicirrata (Brandt). J Exp Mar Biol Ecol 167:215-235

Widersten $B$ (1968) On the morphology and development in some cnidarian larvae. Zool Bidrag Uppsala 37:139-182

Submitted: June 20,1997; Accepted: October 31, 1997

Proofs received from author(s): December 17, 1997 